DOI: $10.14451 / 2.157 .37$

\title{
ПРАВОВОЕ РЕГУЛИРОВАНИЕ КОРПОРАТИВНЫХ ДОГОВОРОВ В ЗАРУБЕЖНЫХ СТРАНАХ
}

\author{
(c) 2021 Мамедов Сулейман Джаванширович \\ студент магистратуры \\ Финансовый университет при Правительстве Российской Федерации, Россия, Москва \\ E-mail: mamedov.sulejman2016@yandex.ru
}

Институт корпоративного договора является сравнительно молодым институтом для российского права, но для стран, рассмотренных в данной статье, данный институт он уже устоялся.

Рассмотрение корпоративного договора в данной статье построено следующим образом: в каждом государстве (Италия, Германия, Великобритания и США), обратились к таким вопросам как: 1) становление и генезис корпоративного договора, как регулятора правоотношений между участниками объединений различных организационно-правовых форм; 2) некоторые особенности и специфика корпоративного договора, характерные для отдельных зарубежных государств.

В конце был сделан вывод, где проведен сравнительный анализ института корпоративного договора в России и рассмотренных государствах.

Ключевые слова: корпоративное право, корпоративный договор, учредительный договор, зарубежные страны, юридическое лищо, Гражданский кодекс, судебная практика.

Роль корпоративного договора как в российском так и в зарубежном праве в качестве одной из форм установления, изменения обязательственных прав и обязанностей участников хозяйственных обществ постепенно возрастает. Следует рассмотреть и проанализировать роль и становление института корпоративного договора в зарубежных странах, чем и обусловлена актуальность темы данной статьи.

Целью статьи является анализ применения корпоративного договора в зарубежных правопорядках.

Для достижения вышеуказанной цели необходимо будет решить следующие задачи:

- становление и генезис корпоративного договора, как регулятора правоотношений между участниками объединений различных организационно-правовых форм;

- некоторые особенности и специфика корпоративного договора, характерные для отдельных зарубежных государств.

Зарубежные правопорядки предусматривают две основные модели корпоративных соглашений: континентально-европейская и англосаксонская.

Для более детального и всестороннего рассмотрения данного института, следует рассмотреть и проанализировать корпоративный договор в таких государствах как Италия, Германия, США и Великобритания.

Главным и основополагающим для европей-

ского корпоративного права, считается принцип отделения личности и имущества юридического лица от личности и имущества его участников.

Поэтому в странах континентальноевропейской модели, законодательством воспринята органическая концепция сущности юридического лица, основной постулат которого состоит в следующем: «организация - не «продукт» согласования воль физических лиц и заключения ими договора, становящегося учредительным документом, а самостоятельный, обладающий автономной волей субъект права, который нельзя охарактеризовать в качестве простой совокупности граждан» [3, с. 136-139].

Корпоративные договоры на территории республики Италия, стали появляться начиная с 80-х гг. XX века. Несмотря на это, как и в других странах, к таким соглашениям суды относились крайне скептически. Обоснования во многом были схожи: невозможность существования иных документов, регулирующих внутренний порядок общества, кроме как учредительных; конфликт интересов самой компании и сторон такого соглашения, в силу чего последнее признавалось ничтожным. Такая негативная судебная практика просуществовала до конца $\mathrm{XX}$ века, однако это не искоренило полностью возможность заключения таких договоров. Все обширнее применялась практика зарубежного инвестирования в компании по праву иностранных государств (в частности США, Великобрита- 
ния), где уже применялись нормы, регулирующие корпоративные договоры. Неформально, но бизнес диктовал свои условия, на которые законодателю все сложнее было не обращать внимание. И эта тенденция вовлечения и применения иностранного права в регулировании деятельности компаний привела к ожидаемому успеху.

В 2003 г. в Гражданский кодекс Италии были внесены изменения на основании Декрета № 6 от 17.01.2003 г. Благодаря этому в отдельные статьи были внесены дополнения, на основании которых законодатель предоставил возможность заключать корпоративные договоры. Причем в ст. 2341 Гражданского кодекса Италии (сопутствующие корпоративные-правовые соглашения (dei patti parasociali)), такое право предоставлялось не только публичным, но и непубличным компаниям [7].

Итальянский корпоративный договор можно классифицировать на следующие виды:

1) соглашение о согласовании позиций перед голосованием на общем собрании;

2) соглашение об ограничении приобретения либо отчуждения акций.

Стоит еще отметить, что итальянский корпоративный договор (как и немецкий) порождает обязательства только между сторонами и не влечет последствий отдельно для компании.

Гражданский кодекс Италии в п. 1 ст. 2341-bis определяет предмет корпоративных договоров как права голоса из акций в форме установления порядка реализации данных прав, а также права собственности на акции в форме их ограничения. Цель корпоративных договоров определена как совместное осуществление управления обществом, а также сохранение структуры корпоративной собственности.

Таким образом, гражданское право Италии императивно ограничивает предмет подобных соглашений.

В Гражданском кодексе Италии отсутствуют положения о бессрочных корпоративных договорах, поскольку стороны вправе заключить корпоративный договор на срок не более пяти лет. В случае, если стороны заключают бессрочный договор, то он, во-первых, действует в течение пяти лет, во-вторых, любая из сторон вправе в одностороннем порядке расторгнуть его, уведомив других участников соглашения за 180 дней. В Италии даже на уровне судебной практики не признается возможность распространения условий корпоративного договора на само общество [1, с. 19-22].

В Гражданском кодексе Италии, а именно в ст. 2341-bis используется термин «Patti parasociali» в переводе на русский, который звучит, буквально как «соглашение, относящееся к обществу», при этом итальянский законодатель не использует прилагательного «corporativo» («корпоративный»), так как уже само слово «корпорация» используется в достаточно узком значении, как правило, для обозначения объединений, основанных на членстве, иногда без создания юридического лица, к примеру, профсоюзы. А с другой стороны, в европейском континентальном праве общепризнана обязательственно-правовая, а не корпоративная природа акционерных соглашений [5, с. 58-59].

В немецком праве соглашения между участниками одной компании, имеющей целью извлечение прибыли, стали заключаться с начала $\mathrm{XX}$ столетия. По своей структуре они имели общие черты с современным корпоративным договором, в частности в них регулировались вопросы состава органов управления, а точнее его формирования исходя из голосования.

Тем не менее, такие договорные конструкции воспринимались немецкими судами крайне неодобрительно. В случае возникновения каких-либо споров, исходя из существа таких соглашений, суд признавал их противоречащими действующему на то время законодательству, а значит и не возможными к существованию.

В подтверждение этого утверждения достаточно обратиться, к решению Верховного Имперского Суда от 1904 г., в котором «...признавался ничтожным договор некоторых акционеров о совместном формировании совета директоров определенным образом на общем собрании....» [2, с. 29].

Базировалась данная позиция суда на том, что идея о договорном голосовании с целью удовлетворения интересов некоторых акционеров противоречит интересам самого общества и, тем самым, может ограничивать его независимость как самостоятельного субъекта правоотношений.

Это решение во многом стало прецедентом для последующих судебных разбирательств по тем же предметам и основаниям. Однако немецкая правовая система не стояла на месте и все существеннее подстраивалась под современные реалии.

Уже в 1967 г. Верховный суд ФРГ все же при- 
знал действительным корпоративный договор, который нарушал положения учредительного документа корпорации [4, с. 42-43]. Это был своего рода переломный момент во взглядах суда относительно существования таких соглашений между участниками внутри компании.

Тем не менее всеобщее признание и положительная регламентация судами корпоративных договоров на территории Германии активно прослеживалась лишь с 90-х гг. прошлого столетия.

На сегодняшний день как в Германском гражданском уложении, так и в корпоративном законодательстве отсутствуют нормы, посвященные регулированию института корпоративного договора. Можно только предположить, что к такому договору применяются общие положения об обязательствах.

Еще одна особенность Германского корпоративного договора заключается в том, что он признается как соглашение, порождающее обязательства только между участниками общества, но не самого общества. Положения такого соглашения не могут противоречить уставу, а также изменять структуру управления в обществе, то есть они не способны породить никакого корпоративного эффекта.

Для сравнения, в российском законодательстве есть нормы, позволяющие на основании условий корпоративного договора проголосовать на общем собрании общества за включение в устав положений, определяющих структуру органов и их компетенцию (абз. 3 п. 2 ст. 67.2 ГК РФ), а также признать недействительным решение органа общества, которое противоречит ранее заключенному корпоративному договору, сторонами которого были все участники общества (п. 6 ст. 67.2 ГК РФ).

Не менее интересным является и тот факт, что объединение участников общества на основании корпоративного договора, представляется в виде товарищества внутри существующего уже юридического лица.

Так М.С.Варюшин говорит об этом следующим образом: «Судебная практика рассматривает корпоративные договоры как соглашения о товариществах, причем объединения акционеров признается товариществами гражданского права ... их еще именуют «внутренними» или «скрытыми» товариществами» [2, с. 31].

На территории Соединенного Королевства корпоративные договоры, существовавшие в виде соглашений между участниками коммерческих организаций, стали активно заключаться в профессиональном кругу уже в первой половине XIX века.

K институту корпоративного договора, каким мы видим его сегодня, больше всего близки соглашения того времени, которые носили название соглашение акционеров (shareholders agreement).

М.С. Варюшин определяет соглашение акционеров (shareholders agreement) следующим образом: «в 1840-х гг. термин «shareholders agreement» означал учредительный договор акционерного товарищества, определявший размер уставного капитала и ежегодно распределяемых дивидендов», что явно показывает принадлежность такого соглашения к договорам, регулирующим корпоративные отношения [2, с. 16].

Однако необходимо отметить, что в то время соглашение акционеров (shareholders agreement) фактически было тождественно учредительному договору.

Но так было не всегда. Ситуация по данному вопросу кардинально изменилась в 50-е гг. XIX века, а именно с принятия в 1856 г. Закона об акционерных обществах (Joint Stock Companies Act). Данный акт четко разграничил документы на:

- необходимые для учреждения компании, такие как учредительный договор и Устав общества;

- регулирующие обязательственные отношения об осуществлении прав, принадлежащих участнику такого общества.

Ко второму виду и было отнесено соглашение акционеров (shareholders agreement), которое с того времени утратило характер учредительного договора.

Следует отметить, что на практике нередко встречались соглашения иного вида, как разновидность соглашения акционеров (shareholders agreement). Довольно часто были случаи, когда сами участники общества заранее договаривались как именно им голосовать по определенному вопросу на общем собрании. Думается, что в силу своего консерватизма, англичанам было недостаточно одного лишь устного соглашения, так как порой от голосования зависела дальнейшая судьба компании. Как следствие, с целью подтверждения словесных намерений, участники общества заключали своего рода договор, предусматривающий кому и как из участников 
голосовать, а кому и вовсе воздержаться от голосования.

Так, М.С.Варюшин говорит об этом следующим образом: «... с прецедентного дела Puddephat v Leith (1916), где договорное обязательство голосовать по акциям определенным способом было признано законным и подлежащим судебной защите, можно говорить о допустимости заключения так называемых «соглашений о голосовании» (voting agreements)» [2, с. 17].

Эволюция применения корпоративного договора в США не значительно отличается от Соединенного Королевства, так как во многом данный институт прошел практически те же этапы на пути к официальному законодательному закреплению со стороны государства. Так уже с середины XIX в. в штатах можно встретить договорные конструкции, представляющие собой соглашения между акционерами.

С появлением таких конструкций у арбитражных судов вырабатываться скептическое отношение к самой возможности существования таких соглашений.

Это прослеживается в большом количестве негативных судебных решений по разрешению споров, вытекающих из заключения договоров между участниками общества.

Позиция судов начало постепенно меняться лишь во второй половине XX века. Этому способствовал принятый в 1950 г. Закон о модельной бизнес-корпорации (Model Business Corporation Act), который впервые содержал положения, по- зволяющие голосовать на собрании по доверенности через представителей, а также порядок учреждения голосующих трастов[6].

С этого времени соглашения заключенные между акционерами о голосовании стали признаваться действительными. Однако стоит отметить, что не все штаты, даже на сегодняшний день, применяют положения данного акта одинаково: одни ратифицировали его полностью, другие только отдельные положения.

Рассмотрев корпоративные договоры применительно к различным правовым семьям, следует отметить, что несмотря на то, что Россия относится к романо-германской правовой системе, вопросы, связанные с правовым закреплением корпоративного договора, существенно отличаются от Германского права. Поскольку, на сегодняшний день как в Германском гражданском уложении, так и в корпоративном законодательстве отсутствуют нормы, посвященные регулированию института корпоративного договора, а с другой стороны, германское право исходит из приоритета устава по отношению к корпоративному договору.

Российское право, в вопросах, которые связаны с правовым закреплением корпоративного договора как самостоятельную норму-регулятор, по своим признакам тяготеет к английскому праву, предоставляет участникам корпоративного договора большую свободу действий, чем в аналогичных правоотношениях государств с романо-германской правовой системой.

\section{Список литературы}

\section{Юридическая литература}

1. Алиев Т. Т. О сущности правовой природы корпоративного договора // Гражданское право. 2015. № 1 . С. 19-22.

2. Варюшин, M. С. «Гражданско-правовое регулирование корпоративных договоров: сравнительный анализ»: дис. канд. юрид. наук: 12.00.03 / М., 2015.-202 с.

3. озлова Н. В. Понятие и сущность юридического лица. Очерк истории и теории: Учебное пособие. М., 2003.$316 \mathrm{c}$.

4. Степанов Д. И., Фогель В. А., Шрамм Х. И. Корпоративный договор: подходы российского и немецкого права к отдельным вопросам регулирования Германии/ ВАС 2012. № 10. С. 22-69.

5. Трубина М.В. Гражданско-правовое регулирование акционерных соглашений в России и странах континентальной Европы. Дис. канд. юрид. наук. М., 2015.-194 с.

\section{Электронные ресурсы}

6. Model Business Corporation Act (Revised)/The Business Lawyer. 1950. [Электронный pecypc]/ http://www. lexisnexis.com/documents/pdf/20080618091347_large.pdf. (дата обращения: 27. 06. 2021).

7. Nuovo codice civile. [Электронный ресурс] // Universocoop: сайт. URL: http://www.universocoop. it/codice/ art_2341-ter.html. (дата обращения: 25.06. 2021). 